\title{
Somogy megye pöszörlegyeinek katalógusa (Diptera: Bombyliidae)
}

\author{
TÓTH SÁNDOR
}

Tóth S.: Checklist of bee-flies of Somogy county (Diptera: Bombyliidae)

Abstract: The bee-fly fauna of Somogy county is mostly unknown, more species are expected to be collected mainly on sandy areas. The 23 species, recorded so far, make up only one third of the known Hungarian fauna. The following interesting elements found in this area are worth mentioning: Anthrax varius Fabricius, 1794, Bombylosoma nigriceps (Loew, 1862), Bombylosoma unicolor (Loew, 1855), Micomitra stupida (Rossi, 1790), Systoechus gradatus (Wiedemann in Meigen, 1820).

\section{Bevezetés}

A közepes nagyságú Diptera családnak mintegy 5000 ismert faját tartják nyilván. A palearktikus régióban kb. 1400, Európában 336 fajukat találták. Magyarország faunáját hozzávetóleg 80-85 faj alkotja, közülük jelenleg 69 elófordulását tekinthetjük bizonyítottnak. Somogy megye pöszörlégy faunája még kevésbé feltárt, fóleg a homokterületek alaposabb kutatásától várható további fajok elókerülése. A jelenleg rendelkezésre álló adatok többsége a DunaDráva Nemzeti Parkból, a Boronka-melléki Tájvédelmi Körzetból és a Zselicból származik. Már az eddig kimutatott 23 faj között is több, faunisztikai szempontból érdekesebb elem található: Anthrax varius Fabricius, 1794, Bombylosoma nigriceps (Loew, 1862), Bombylosoma unicolor (Loew, 1855), Micomitra stupida (Rossi, 1790), Systoechus gradatus (Wiedemann in Meigen, 1820).

\section{A Somogyból ismert fajok jegyzéke}

Anthrax leucogaster Wiedemann in Meigen, 1820 - Csiby 1981, Tóth 1992, 1995, Tóth (elốkészületben)

Anthrax varius Fabricius, 1794 - Tóth (elökészületben). Ritka, Somogy megyében eddig csak Darányból ismerjük.

Bombylius ater Scopoli, 1763 - Tóth 1995, Tóth (elökészületben)

Bombylius canescens Mikan, 1796 - Tóth (elökészületben)

Bombylius cinerascens Mikan, 1796 - Tóth (elókészületben)

Bombylius discolor Mikan, 1796 - Tóth 1995, Tóth (elökészületben)
Bombylius fimbriatus Meigen, 1820 - Tóth (elökészületben)

Bombylius major Linnaeus, 1858 - Tóth 1992, 1995, Tóth (elókészületben)

Bombylius vulpinus Wiedemann in Meigen, 1820 - Tóth (elökészületben)

Bombylosoma nigriceps (Loew, 1862) - Tóth (elókészületben). Ritka faj, Somogy megyében csak a Barcsi Borókásban gyújtötték.

Bombylosoma unicolor (Loew, 1855) - Csiby 1981, Tóth (elökészületben). Ritka faj (Barcsi Borókás, Őrtilos)

Conophorus virescens (Fabricius, 1787) Tóth (elókészületben) 

1992

Exhyalanthrax afer (Fabricius, 1794) - Tóth

Hemipenthes morio (Linnaeus, 1758) - Csiby 1981, Tóth 1992, 1995, Tóth (elökészületben) 1992

Lomatia lateralis (Meigen, 1820) - Tóth

Lomatia sabaea (Fabricius, 1781) - Tóth (elôkészületben)

Micomitra stupida (Rossi, 1790) - Ábrahám 1998, Tóth (elökészületben). A magyarországon korábban csak Ágasegyházáról ismert ritka fajt, Ábrahám Levente mutatta ki Darányból és Örtilosról, egy hangyaleső (Euroleon nostras) új parazitájaként.
Phthiria canescens Loew, 1846 - Tóth (elókészületben)

Spogostylum aethiops (Fabricius, 1781) Tóth (elókészületben)

Systoechus gradatus (Wiedemann in Meigen, 1820) - Tóth 1995, Tóth (elökészületben). Ritka faj, Somogyban csak a Duna-Dráva Nemzeti Parkban találták.

Villa circumdata (Meigen, 1820) - Tóth (elökészületben)

Villa halteralis (Kowarz, 1883) - Tóth 1992, Tóth (elökészületben)

Villa hottentotta (Linnaeus, 1758) - Csiby 1981, Tóth 1992, 1995, Tóth (elökészületben)

\title{
Irodalom
}

ÁBrahám L. 1998: Micomitra stupida (Diptera: Bombyliidae): a new parasite of Euroleon nostras (Neuroptera, Myrmeleontidae) - Dunántúli Dolg. Term. tud. Sorozat 9: 421-422.

CsıBY M. 1981: Adatok a Barcsi Borókás kétszárnyú (Diptera) faunájához - Dunántúli Dolg. Term. tud. Sorozat 2: 149-156.

TóTH S., 1992: Vegyes kétszárnyú (Diptera) adatok a Boronka-melléki Tájvédelmi Körzet faunájához - Dunántúli Dolg. Term. tud. Sorozat 7: 273-287.

TótH S., 1995: Adatok a Dráva mente kétszárnyú (Diptera) faunájához - Dunántúli Dolg. Term. tud. Sorozat 8: 161-172.

TóTH S. Adatok Somogy megye kétszárnyú (Diptera) faunájához - Somogy Megy. Múz. Közlem., (elökészületben)

\section{Checklist of bee-flies of Somogy county (Diptera: Bombyliidae)}

\section{SÁNDOR TÓTH}

The bee-fly fauna of Somogy county is hardly known. More species are expected to be collected mainly on sandy areas. The 23 species, recorded so far, make up only one third of the known Hungarian fauna. The following interesting elements found in this area are worth mentioning: Anthrax varius Fabricius, 1794, Bombylosoma nigriceps (Loew, 1862), Bombylosoma unicolor (Loew, 1855), Micomitra stupida (Rossi, 1790), Systoechus gradatus (Wiedemann in Meigen, 1820).

\author{
Author's address: \\ Dr. Sándor TóTH \\ $\mathrm{H}-8420$ Zirc \\ Széchenyi u. 2. \\ HUNGARY
}

